\title{
The influence of health and environment-focused values on restaurateur satisfaction in organic restaurants: a descriptive analysis in Spain
}

\author{
La influencia de los valores saludables y \\ medioambientales sobre la satisfacción del \\ restaurador en los restaurantes ecológicos: un \\ análisis descriptivo en España
}

\author{
Luis Manuel Cerdá Suárez 1 \\ RAFAEL Robina RamíREZ ${ }^{2}$ \\ Pedro Ramiro Palos SÁnCheZ ${ }^{2}$ \\ Universidad Internacional de La Rioja (Spain) \\ Universidad de Extremadura (Spain)
}

Recibido el 15 de noviembre de 2016, aceptado el 15 de septiembre de 2017

Publicado online el 20 de febrero de 2018

$\mathrm{N}^{\mathrm{o}}$ de clasificación JEL: M21, M31

DOI: $10.5295 / \mathrm{cdg} .1607181 \mathrm{c}$

\begin{abstract}
:
As a consequence of the increasing importance of the organic food in several countries, there are many theoretical and empirical studies focused on analyzing whether the health values or rather the environmental attitudes of the restaurateurs, are the most influential factors on their satisfaction. However, it is very important to differentiate the impact of these factors in order to improve the restaurateur satisfaction in the marketing of organic labeled foods.
\end{abstract}

As most studies in restaurants are related to customer satisfaction, this paper deals with a novel topic relating promotion and differentiation in organic restaurants and particularly describing restaurateur satisfaction (i.e. manager satisfaction). In the framework of a research project focused in organic restaurants, in this paper we investigate how restaurant managements' attitudes influence decisions to promote organic foods as inputs on menus. Different combinations of promotional attributes of an organic menu are considered and a wide spatial representation of cross-sectional nature has been obtained, and an investigation of chefs' decision-making criteria based on a questionnaire was carried out to collect data. We illustrate how is possible to manage the promotion of the organic restaurants in Spain and the implications of these findings for restaurants are discussed. The main contribution of this work is that there is a potential niche for restaurants in the marketing of organic labeled

\footnotetext{
1 Facultad de Ciencias Jurídicas, Sociales y Humanidades, Av. de la Paz, 137, 26004-Logroño (España). luis. cerda@unir.net

2 Facultad de Empresa, Finanzas y Turismo, Av. Universidad, s/n.,10003-Cáceres (España). rrobina@unex.es; ppalos@unex.es
} 
foods, in order to facilitate the promotion of organic food consumption in restaurants highlighting the attributes on which to establish the proposition of value.

\section{Keywords:}

Health value, organic food, restaurant management, restaurateur, differentiation, Spanish market.

\section{Resumen:}

Como consecuencia de la creciente importancia de los alimentos ecológicos en varios países, existen estudios teóricos y empíricos centrados en analizar si son los valores saludables, o más bien las actitudes ambientales en restaurantes ecológicos, los factores más influyentes en su satisfacción del restaurador. Sin embargo, es muy importante diferenciar el impacto de estos factores, para mejorar la satisfacción de estos en la promoción de sus restaurantes.

La mayor parte de los estudios sobre restaurantes ecológicos están referidos desde la perspectiva de los consumidores. Con un enfoque diferente, este trabajo se relaciona con la promoción y diferenciación y, en particular, la satisfacción de sus restauradores o gerentes. En el marco de un proyecto de investigación realizado en España, en este trabajo investigamos cómo las actitudes de los gerentes de restaurantes influyen en las decisiones de promover los alimentos ecológicos. A partir de una amplia representación espacial de naturaleza transversal, y con un cuestionario como instrumento de obtención de información, en este artículo se ilustra cómo gestionar la promoción de los restaurantes ecológicos en España, y se discuten las implicaciones de estos hallazgos. La principal contribución de este trabajo consiste en facilitar la promoción del consumo en los restaurantes ecológicos, resaltando los atributos en que fundamentar su propuesta de valor.

\section{Palabras clave}

Valor saludable, alimentación ecológica, gestión del restaurante, restaurador, diferenciación, mercado español. 


\section{INTRODUCTION}

Recently, the diffusion of sustainable diets and the importance of multilevel policies and actions that address healthy and environmentally friendly foods (Vega and Ubbink 2008) have undergone a great growth worldwide (Camillo et al. 2010). This situation has led to important changes in the way in which the restaurateurs and chefs disseminate information based on the available scientific evidence on health and environmental impact of organic food (Roberts et al. 2008; Aertsens et al. 2011; Daunfeldt and Rudholm 2014; MAGRAMA 2014a, b; Gagić et al. 2015; Robina et al. 2015; Sundbo 2016; Hoek et al. 2017).

Focusing on the supply-side perspective, the marketing of organic labeled foods becomes compulsory. Several studies have raised questions about how restaurants can promote sustainable intentions and have an advantage in the competitive food service market (e.g. Zanoli et al. 2004; FEHR 2012; OTA 2013; Willer et al. eds. 2013; Cerdá and Robina 2015a). However, definitions and measurements of some concepts are difficult to get. For this reason, it is important to develop conceptual and empirical frameworks describing restaurateur satisfaction and taking a generic starting point, based on the existing Marketing and Business literature.

There is effectively another construct from supply-side perspective which is the "managerial decisions" on the role played by menu design. Managers, as a gate-keepers, who are in charge of approving any changes made to restaurant business operations, have to consider carefully what changes have to be done to raise the business success, customer satisfaction and consumer loyalty (Raab and Mayer 2007). To date, little research has been done related to managerial decisions so as to be more responsible to consumer food choice when they eat out (Ozdemir and Caliskan 2014). This managerial opinions are not only based on 'price' factor, rather on 'perceived value for money' which consumers evaluate the quality of food and service such as restaurant ambience, food presentation offer in restaurants (Price et al. 2016). The highly competitive restaurant maker ought to restaurateurs to work hard to keep up the costumer expectations in order to differentiate themselves from the competition (Yim et al. 2014). Managerial decisions trying to be quite accurate to adopt managerial policies base on the revenue and the quality management techniques that incorporate smart pricing strategies, quality guarantee campaigns and aggressive marketing approaches, among others (Raab et al. 2009).

As most studies in restaurants are related to customer satisfaction, this paper deals with a novel topic describing restaurateur satisfaction with restaurant menu preferences, i.e. manager satisfaction (Chen and Gursoy 2001; Harris et al. 2017). The intention in this research is to provide relatively simple frameworks, drawing as far as possible on concepts couched in the literature on local foods and practices pertaining to restaurants. The conceptualization that we have developed is related to direct marketing and consumer behavior, but so far draws mainly on the literature of what has come to be called the theory of planned behavior (Ajzen and Fishbein 1975; Cordano and Frieze 2000; Ajzen and Fishbein 2005; Quintal et al. 2010).

The main focus in Government institutions is on human or institutional development, and Social Marketing emerged for the same reason. Both Social Marketing and Government institutions are in search of strategies for effective changes. In this paper, a wide spatial representation of cross-sectional nature was conducted at restaurants between Sep- 
tember and November 2014 in Spain, within the framework of a research project focused in organic restaurants. The ultimate aim of this work is to assess the impact of different combinations of valued organic food-focused attributes on restaurateur satisfaction, considering some locational and commercial characteristics of his/her business.

This work is grounded in a behavioral framework based on theories put forth by Ajzen and Fishbein (1975) and Ajzen and Fishbein (2005). According to the Theory of Planned Behavior, Ajzen and Fishbein (1975) suggested that intentions influence behavior. Carpenter and Reimer (2005) and Sharma et al. (2014) highlight that two constructs of this theory -attitudes and perceived behavioral control- influence behavior. This research is further guided by attitudinal values of organic food that include several elements such as healthy and environmentally friendly food behaviors (Mallinson et al. 2016). This paper is based on empirical evidence demonstrating how restaurants can promote sustainable intentions and have an advantage in the competitive food service market (Campbell and DiPietro 2014; MAGRAMA 2014a, b; Cerdá and Robina 2015a, b).

The outline of this paper is the following. First, a review of the literature on topics and research design is conducted. Second, a methodological procedure of research and results are presented. Third, a section is devoted to discussions, conclusions, implications and further research.

\section{CONCEPTUAL FRAMEWORK AND HYPOTHESIS}

According to Sharma et al. (2014), Theory of Planned Behavior's theoretical framework is typically selected when investigating choice, purchase and adoption behaviors, mostly among consumers but also in management contexts. In fact, Theory of Planned Behavior (Ajzen and Fishbein 1975, 2005) has been used extensively in hospitality research to investigate consumer purchase intentions: use of lodging websites (Jeong and Lambert 2001), tourist destination and loyalty (Chen and Gursoy 2001), hotel purchase intentions (Kim and Kim, 2004); genetically modified foods (O'Fallon et al. 2007); green practices and lodging industry (Lee et al. 2010); and travel decision-making (Quintal et al. 2010). While this theory has been applied in management contexts, such studies are scarce in the hospitality literature. For example, some of the management contexts of discussions related to this theoretical framework include: food safety behaviors (Roberts et al. 2008), pollution reduction preferences of managers (Cordano and Frieze 2000), knowledge-sharing perceptions and behavior of managers (Lin and Lee 2006), unethical and fraudulent reporting of financial behavior (Carpenter and Reimer 2005) and employee decisions about new technology (Morris et al. 2005). However, it appears that no studies have used this theory to investigate managements' perceptions and behaviors in the context of restaurants' food decisions.

\subsection{Health values and restaurateur satisfaction}

In Business and Marketing studies, the importance of the manager or retailer satisfaction has been identified by several researchers as a key indicator for success in the market. 
Thus, in the context of marketing strategies, a successful restaurant 'is one that attracts consumers, which is reliable and generates satisfaction to users' (Kim and Kim 2004; Martinez et al. 2010; Kim and Chung 2011). For example, Kang et al. (2015) and Kwok et al. (2016) examined several designs and attributes that compose the quality of organic menus and contribute to the manager and consumer satisfaction.

Several aspects such as appearance and presence of organic food ingredients increasingly became important challenges for restaurants and marketers; this is the reason why they have to present relevant information in menu items at restaurants and their websites in order to satisfy the needs for search to consumers (Davies et al. 1995; Cuperschmid and Tavares 2002).

In Hospitality Management, restaurateur satisfaction is defined as the subjective assessment carried out by the manager him/herself of his/her experiences and results with personality traits and beliefs of an object or situation, either positive or negative (Tarkiainen and Sundqvist 2005; Mallinson et al. 2016). Satisfaction on organic food is an emotional response of the individual as a result of a global perception of all the attributes that compose the product/service; therefore, satisfaction is a signal of the individual favorable attitude to the offer (Torjusen et al. 2001; Kwok et al. 2016). From an integrative perspective, satisfied restaurateurs and consumers can stay longer interacting through the restaurant experiences and consumers can visit restaurants more frequently, or generate positive opinions to the other users.

Although in the field of consumer behavior a good culinary experience does not guarantee the consumer satisfaction, several researchers point out that it has a great impact on it (Poulston et al. 2011; Campbell and DiPietro 2014; Goetzke et al. 2014). In fact, different healthy attributes (nutritional values, taste, appeal of food and texture) are frequently used to increase the preference for organic products and as a result, they impact on high levels of consumer satisfaction. For example, Ajzen and Fishbein (2005) and Tarkiainen and Sundqvist (2005) identified attitudinal attributes as a relevant dimension of consumer satisfaction, emphasizing the importance of factors such as norms, motivations and intentions. Thus, nutritional and healthy attributes can evoke positive feelings when the consumer is browsing on food choices; this is because the product is better perceived and it is easier to remember (Harper and Makatouni 2002). Literature review and the available research papers on this topic show that a high quality and the safety of food served in restaurants lead to a higher level of satisfaction. In addition, perceived tangible benefits can generate higher levels of organic food purchasing preference for consumers and restaurateurs (Lai and Chen, 2011, Sharma et al. 2014).

Therefore, health value features are perceived as influencing restaurateur satisfaction. When healthy and nutritional information on organic restaurant menus satisfies the expectations of consumers and restaurateurs, their consumption is likely to increase (Kang et al. 2015). The review of the literature on the organic food and restaurants carried out in the context of this research has allowed to question the main relevant attributes on the level of restaurateur satisfaction in the marketing of organic labeled foods, in order to capitalize and promote organic products as inputs to their menus. To explore the issue discussed previously several specific hypotheses were developed.

Regarding the health values, and considering the high level of information showed by the perceived benefits of organic menus to capture the attention of restaurateurs, the 
above-mentioned review of the literature allows to point out the following hypotheses, based on the statement that a healthy image will lead to a higher restaurateur satisfaction:

$\mathrm{H}_{1}$ : The presence of the nutritional attributes in the organic food will have a direct impact on the level of restaurateur satisfaction.

$\mathrm{H}_{2}$ : The presence of the taste and smell in the organic food will have a direct impact on the level of restaurateur satisfaction.

$\mathrm{H}_{3}$ : The existence of texture of the items in the organic food will have a direct impact on the level of restaurateur satisfaction.

\subsection{Environment-focused values and restaurateur satisfaction}

In hospitality businesses (including service and retail), health and environmentalism presented to consumers in their promotion tasks are revealed as two key factors for success in the information search process and consumers' attention to the business (Mikkelsen 1993; Murphy and Smith 2009). In addition, these promotional tasks are some of the most frequent activities of the restaurateurs on the Internet (Jeong and Lambert 2001; Boyne and Hal 2004).

Regarding the environment-focused values in organic food, several authors argue that, when consumers are looking for commercial information in the purchase process, different attributes such as environmentally friendly food aspects, food safety concerns and sustainability related food quality can facilitate its preference; as a consequence, the need to gather information and process heuristically lead to a higher level of consumer satisfaction (Chryssohoidis and Krustallis 2005; Sharma et al. 2014; Hoek et al. 2016; Kwok et al. 2016). Moreover, a number of studies have shown correlations between the perceived information, experiences and attitudes towards environmentally friendly food (Shepperd et al. 2005; Manaktola and Jauhari 2007; Rivera 2007; Bauer et al. 2013; Jacob and Guéguen 2015; Chuck et al. 2016; Thøgersen 2017). The ultimate outcome of restaurateur satisfaction is in behavioral use, meaning that consumers select a particular organic restaurant in the expectation that they will find reliable information in their restaurant experiences. Thus, it is supposed these attributes in the organic food will have a positive effect on the level of restaurateur satisfaction when restaurants are finding ways to promote the beneficial aspects of organic products.

As well as consumers are looking for information in the organic food buying process, in which they need to evaluate several alternatives when they are comparing the different product characteristics, in the field of Hospitality Management it is necessary to assess the environment-focused values in order to appreciate its importance on restaurateur satisfaction in the development of their commercial and promotional tasks (Davies et al. 1995; Magnusson et al. 2003; Marketzki and Tuckermanty 2007; Lee et al. 2010; Sharma et al. 2014). Therefore, it seems reasonable to suppose that a high level of "environmentally friendly", that is to say, the greater relevance of the environmental aspects in organic food which consumers can consider in order to obtain the information they need, the higher level of restaurateur satisfaction in their promotional activities. In this sense, according to Sharma et al. (2014) and Jacob and Guéguen (2015), several features such as environment-focused green attributes, interest in food safety concern and perceived quality in organic 
food reveal higher scores on those restaurants with high levels of perceived importance of various green attributes.

In studies on Marketing and Business there are only few papers that have conducted research related to the relationship between these constructs. Some studies analyze the relationship among environment-focused green attributes, interest in food safety concern and perceived quality in organic food (e.g. Sirieix et al. 2011; Schleenbecker and Hamm 2013; Vitters $\varnothing$ and Tangeland 2015; Bryła 2016; Prada et al. 2017). The review of the literature on this topic of research allows to point out the following hypotheses based on attributes related to achieve a higher organic restaurateur satisfaction:

$\mathrm{H}_{4}$ : The presence of the environmental aspects in the organic food will have a direct impact on the level of restaurateur satisfaction.

$\mathrm{H}_{5}$ : The presence in food safety concern in the organic food will have a direct impact on the level of restaurateur satisfaction.

$\mathrm{H}_{6}$ : The existence of the perceived quality of the items in the organic food will have a direct impact on the level of restaurateur satisfaction.

\section{METHODOLOGY}

In order to analyze the importance of the relationship between these constructs, this research was applied at restaurants that, for a long time, promote health and environmentfocused values based on organic menus, tested in three broad Spanish Regions: Peninsular Spain, the Mediterranean Coast and the South of Spain and the Islands. The total number of chefs and restaurant managers in this research was 109; the specialized literature has frequently used this profile of participants for this type of studies because they are frequent responsible for menu choices (Hutchins and Greenhalgh 1997; Cuperschmid and Tavares 2002; Lockie et al. 2002; IFOAM 2013; Robina et al. 2015).

Two aspects of the methodology should be considered in this research related to: 1) the participants, and 2) the instrument and the detailed procedure for this research.

\subsection{Participants}

Regarding the participants in this study, in order to explore the research proposal between the constructs this research was tested at restaurants located in three broad Spanish regions, named as Peninsular Spain, the Mediterranean Coast and The South of Spain and The Islands (see Table 1). First, this research was applied in the following autonomous communities: Aragon, Asturias, Cantabria, Castile and Leon, Madrid and Navarre. Second, we carried out this research in restaurants located in the east of Spain on the Mediterranean Coast (that is, Catalonia, Murcia and Valencia). Third, restaurateurs located in The South of Spain and The Islands were asked to evaluate the buying decision-making processes of organic restaurants (i.e., Andalusia, Balearic Islands, Canary Islands and Extremadura).

In order to obtain a diverse data set in the sense of an exploratory study, the participants were selected from a range of gastronomic sectors that offered culinary experiences at different businesses and locations, as a form of triangulation to increase validity of the research 
by collecting 'geographically dispersed data'. This strategy of 'extreme sampling' allowed capturing perceptions that are representative of the on-going changes of promotional practice, rather than being solely a reflection of the current marketing systems. Reasons for this comparative design include the fact that differences in culture and purchasing practices may provide insights on each situation, which might otherwise not be apparent. Furthermore, similarities and differences can be discerned, which can provide a theoretical basis as well as a practical implication for promotion generally and at each restaurant in particular.

Table 1

Geographical area of the research in Spain

\begin{tabular}{|c|c|c|}
\hline PENINSULAR SPAIN & $\begin{array}{c}\text { MEDITERRANEAN } \\
\text { COAST }\end{array}$ & $\begin{array}{c}\text { THE SOUTH OF SPAIN AND } \\
\text { THE ISLANDS }\end{array}$ \\
\hline Aragon & Catalonia & Andalusia \\
\hline Asturias & Murcia & Balearic Islands \\
\hline Cantabria & Valencia & Canary Islands \\
\hline Castile and Leon & & Extremadura \\
\hline Madrid & & \\
\hline Navarre & & \\
\hline Basque Country & & \\
\hline
\end{tabular}

Source: Own elaboration.

The participants were selected from a census and the sampling frame coincided with it. In order to evaluate the importance of the restaurateur satisfaction, the participants were randomly asked using a simple random sampling method. This type of organic business is appropriate for three main reasons. First, organic food is especially attractive to the population in this research. Second, this product requires analytic information processing, and the use of simple product presentation in restaurants could accomplish the objective of offering high-quality information which could be easily remembered. Third, organic food and menus are not as standardized as some other products (e.g., fast food items), which minimizes the amount of possible generalized knowledge. That is, explained on the type of product which offers various features, restaurateurs focus on the information of this product to better understand it.

According to the review of the literature on this topic of research (Mondelaers et al. 2009; Hsieh and Stiegert 2011; Price et al. 2016), previously scholars and external experts with knowledge and experience in marketing were contacted in order to appreciate if our questionnaire was adequate to these research objectives (face validity). Secondly, the questionnaire was tested in a small sample of convenience among restaurateurs with similar characteristics to those investigated as the ultimate target, on which eventually the final questionnaire was applied.

In this research restaurateurs filled a questionnaire. The scale on satisfaction was derived from and validated according to the revision of the afore-mentioned literature (Morris et al. 2005; Lin and Lee 2006; Robina et al. 2015). The total number of respondents was 109 and it involved restaurants located in the three broad Spanish regions (Table 1). 


\subsection{Instrument, data collection and analysis}

Regarding the aspects related to the sources of information and the detailed procedure for this research, restaurateurs were asked to fill in a questionnaire (data collection procedure) with the following information: Part I: 'Restaurateur satisfaction', Part II: 'Healthy and environment-focused values' and Part III: 'Identification data of the respondent'. The variables in this research (Part I: scale) were collected in the questionnaire with the scale listed in Likert-type scale ranging from 1 (strongly disagree) to 10 (strongly agree).

Items in the scale set out in the review of the literature on restaurateur satisfaction provided the basis for the development of the instrument of measurement, defined as a structured questionnaire of closed questions, with support in the results of the pre-test incurred in a preliminary test, and derived from the specific context where it was the fieldwork, conducted through the following phases: (1) writing original items about organic food, (2) transformation, addition and / or delete some original items, depending on the semantic and specific context of the geographical areas / regions where the research was conducted, and (3) re-write the questionnaire to the original version in order to assess the correct interpretation of the meaning of the scale in the questionnaire.

An adaptation of the Robina et al. (2015) scale is used to measure the restaurateur satisfaction. There are three reasons for our choice of this scale of measurement: 1) it is a highly operative measure because there is not a very high number of items that compose it; 2) it has appropriate psychometric qualities; 3 ) the geographical scope in Spain is very similar from the socio-economic point of view. This scale considers restaurateur satisfaction in particular with the characteristics reported in the literature, i.e. nutritional attributes, taste-smell and texture.

The present study used Baron and Kenny's (1986) approach to examine the effect of interest in healthy food on two relationships proposed in this research: (1) the relationship between health values and restaurateur satisfaction, and (2) the relationship between environment-focused values and satisfaction. In addition, a median was used to consider responses into categories (a high or low for perceptions) based on the results from descriptive analysis.

Related to the data collection procedure, table 2 shows details of the methodological process of this research. The fieldwork in Peninsular Spain was conducted between September 28 and October 12, 2014, and the fieldwork in the east of Spain on the Mediterranean Coast, and The South of Spain and The Islands was collected between September 28 and October 24, 2014.

Table 2

Methodological process of the research

\begin{tabular}{|c|c|c|c|}
\hline PHASE & ANALYSIS & METHODOLOGY & TECHNIQUE \\
\hline \multirow[b]{2}{*}{$\begin{array}{l}\text { Identification of } \\
\text { variables }\end{array}$} & $\begin{array}{l}\text { Documentary and face } \\
\text { validity }\end{array}$ & Literature review & Bibliographic analysis \\
\hline & $\begin{array}{l}\text { Reliability and cons- } \\
\text { truct validity } \\
\text { analysis }\end{array}$ & $\begin{array}{l}\text { Quantitative research } \\
\text { (analysis of overall } \\
\text { reliability and initial factor } \\
\text { validity) }\end{array}$ & $\begin{array}{l}\text { Descriptive statistics of all items } \\
\text { Cronbach's Alpha } \\
\text { Item-total correlation and factor } \\
\text { analysis } \\
\text { Confirmatory factor analysis }\end{array}$ \\
\hline $\begin{array}{l}\text { Evaluation of } \\
\text { variables }\end{array}$ & $\begin{array}{l}\text { Evaluation of the } \\
\text { variables }\end{array}$ & Quantitative research & $\begin{array}{l}\text { ANOVA model, descriptive } \\
\text { analysis and t-test }\end{array}$ \\
\hline
\end{tabular}

Source: Own elaboration. 
Regarding the data analysis procedure, table 2 shows details of the methodological process of this research. In relation to hypotheses derived from the conceptual framework of this research, the t-test and ANOVA model were proposed and used as described in Section 4.

\section{RESULTS}

\subsection{Descriptive statistics}

According to the methodological process of the research above described, the finding presented in this section derives from empirical analysis. Table 3 shows, in comparative terms, the profile of the restaurants who answered this questionnaire.

As a whole, in this analysis it is worth noting the difference between regions in terms of the number of restaurants in ownership, $88.1 \%$ one and $11.9 \%$ two or more units, as well as the high proportion of restaurants between 11 and 20 years old at this moment in Spain $(44 \%)$. Also, Table 3 shows that restaurants in Spain are older in the coast, the south and the Islands than those located on the peninsula.

Table 3

Descriptive statistics (total sample, data in percentage)

\begin{tabular}{|c|c|c|c|c|}
\hline \multirow[b]{2}{*}{ SAMPLE } & \multicolumn{3}{|c|}{ RESTAURANTS } & \multirow[b]{2}{*}{$\begin{array}{c}\text { TOTAL } \\
\text { RESTAURANTS } \\
(\mathrm{n}=109)\end{array}$} \\
\hline & $\begin{array}{l}\text { PENINSULAR } \\
\text { SPAIN }(n=29)\end{array}$ & $\begin{array}{l}\text { MEDITERRANEAN } \\
\text { COAST }(\mathrm{n}=40)\end{array}$ & $\begin{array}{l}\text { THE SOUTH OF } \\
\text { SPAIN AND THE } \\
\text { ISLANDS }(\mathrm{n}=40)\end{array}$ & \\
\hline $\begin{array}{l}\text { NUMBER OF } \\
\text { RESTAURANTS } \\
\text { IN OWNERSHIP: } \\
\text { One } \\
\text { Two or more }\end{array}$ & $\begin{array}{l}89.7 \\
10.3\end{array}$ & $\begin{array}{l}87.5 \\
12.5\end{array}$ & $\begin{array}{l}87.5 \\
12.5\end{array}$ & $\begin{array}{l}88.1 \\
11.9\end{array}$ \\
\hline $\begin{array}{l}\text { AGE OF THE } \\
\text { RESTAURANT: } \\
0-10 \text { years } \\
11-20 \text { years } \\
>21 \text { years }\end{array}$ & $\begin{array}{c}51.7 \\
41.3 \\
7\end{array}$ & $\begin{array}{c}35 \\
42.5 \\
22.5\end{array}$ & $\begin{array}{c}32.5 \\
47.5 \\
20\end{array}$ & $\begin{array}{c}38.5 \\
44 \\
17.5\end{array}$ \\
\hline $\begin{array}{l}\text { TOTAL RESTAU- } \\
\text { RANTS }\end{array}$ & 100 & 100 & 100 & 100 \\
\hline
\end{tabular}

Source: Own elaboration.

The final version of the questionnaire was a multi-item scale consisting of variables that measure restaurateur satisfaction with all items distributed randomly. Restaurateurs filled the questionnaire and this scale was plotted in random order for self-administration by item sequentially, one after the other. In the end, the scale was represented in ten Likert-terms because not many neutral responses on the assessment of these aspects were found in the 
pre-test. In short, each respondent received each assessment item in random order to avoid some of the effects of biased potential responses.

The final questionnaire was self-administered in the different geographical areas by two interviewers with physical presence and by phone, in order to monitor the understanding of the items included and the scale of the questionnaire (the scale was presented to restaurateurs in positive order, according to the large number of possibilities of response and the review of the theoretical framework described in previous pages, and to facilitate the reading and interpretation of the results presented in this paper).

The above-mentioned questionnaire was sequentially applied in Spain in order to avoid biases in the empirical structure, to validate the stability of the solutions obtained in each step and to generalize the results beyond the sample ones obtained. This cross-validation allows analyzing data with three samples: one of them for the estimation of the previous scales of measure; and the others to cross-validate this analysis (Hair et al. 1998). Finally, the same instrument was applied in the three broad Spanish regions.

In order to test the hypotheses here described, the statistical analysis started with the empirical identification of the variables. Internal consistency of the satisfaction scale (Cronbach's Alpha) was analyzed and the item-total correlation of this scale was measured. Furthermore, the overall reliability of the scale, which showed a coefficient Alpha of 0.967, was estimated (all items were approximately normally distributed). The analysis of the item-total correlation for all variables ranged from 0.716 to 0.885 . In order to achieve a psychometrically sound measurement that holds under cross-validation, exploratory factor analysis was used as an additional step. Given the exploratory nature of this research, the factor analysis of principal components with Varimax rotation was applied on the sample.

The primary goal of exploratory factor analysis is to reduce a large set of measured variables to a smaller set. Exploratory factor analysis can be used to determine whether the hypothesized dimension actually is reflected in the collected data. The first stage in analyzing the data with exploratory factor analysis is checking the conditions for a stable factor structure. To sum up, internal consistency of satisfaction scale was tested: Cronbach's Alpha test, inter-correlation of the items and exploratory factor analysis determined the one-factor structure of this scale.

These findings determined that it was possible to reduce the total number of items in this scale and present a one-factor scale on satisfaction. In this research a confirmatory factor analysis was used, so that the hypothesized factor structure can be tested for its fit to the observed covariance structure. In addition, information is provided (i.e., modification indices) to guide towards further refining this measure. Confirmatory factor analysis was conducted to examine the adequacy of fit of the original one-factor models specified using LISREL 8.7. In this analysis, the results were examined through the three model-data fitting indices selected, that is, CFI, RMSEA and SRMR. Table 4 presents the summary of the model-data fit indices fitting the sample; indices indicated good fit of the overall factor structures. 
Table 4

Summary of Model-Data Fit in CFA for satisfaction scale

\begin{tabular}{|c|c|c|c|c|}
\hline VARIABLE & $\begin{array}{c}\text { CHI-SQUARE / DEGREES } \\
\text { OF FREEDOM }\end{array}$ & CFI & RMSEA & SRMR \\
\hline Restaurateur satisfaction & 2.691 & 0.897 & 0.010 & 0.098 \\
\hline
\end{tabular}

Source: Own elaboration.

\subsection{Data analysis}

In order to test the hypotheses $\mathrm{H}_{1}$ to $\mathrm{H}_{6}$, a restaurateur satisfaction scale was created for further analysis as the mean scoring of the sum of the items that measured individually this construct. The ANOVA model was conducted to compare the satisfaction scale by geographical area in Spain (that is, Peninsular Spain, the Mediterranean Coast and The South and The Islands).

Regarding the hypotheses $\mathrm{H}_{1}$ to $\mathrm{H}_{3}$, when the mean scoring of the satisfaction scale was reviewed, significant differences were found related to taste and smell of the organic products (see Table 5: Sign. p-values < 0.05). Related to the interaction effect among these attributes, no statistically significant differences were found on satisfaction as described in Table 5 (Sign. p-value $>0.05$ ).

Thus, the results showed that restaurateur satisfaction was impacted by taste and smell related to the health values regarding to the hypotheses $\mathrm{H}_{1}$ to $\mathrm{H}_{3}$. However, it was not allowed to see a significant relationship on the satisfaction of the restaurateurs, in terms of interaction. Given the exploratory nature of this paper, the results of this study pointed out these individual perceptions of managers on nutritional attributes are the foundation of healthy food at organic restaurants. The findings of this research confirmed that managers and chefs who place value on health are satisfied, and they are also more likely to control their decisions on what organic menus offer to consumers. Similarly, when a healthy menu item seems to be attractive in terms of its texture, restaurateurs are likely to be satisfied to the organic menu. By contrast to the review of the theoretical framework described in previous pages, taste and smell are relevant only for certain respondents in this research. Hypotheses $\mathrm{H}_{1}$ to $\mathrm{H}_{3}$ were tested and only $\mathrm{H}_{2}$ was accepted (result shown in Table 5).

Table 5

Hypothesis related to the impact of health values on satisfaction $\left(\mathrm{H}_{1}-\mathrm{H}_{3}\right)$

\begin{tabular}{|c|c|c|c|c|}
\hline SOURCE OF VARIATION & $\begin{array}{c}\text { DEGREES OF } \\
\text { FREEDOM }\end{array}$ & $\begin{array}{c}\text { ROOT MEAN } \\
\text { SQUARE }\end{array}$ & F & Sign \\
\hline Nutritional attributes & 2 & 1.299 & 0.914 & 0.404 \\
\hline Taste / smell & 2 & 6.807 & 5.264 & 0.007 \\
\hline Texture & 2 & 0.837 & 0.503 & 0.480 \\
\hline Nutritional $\mathrm{x}$ taste / smell & 2 & 0.658 & 1.189 & 0.277 \\
\hline Nutritional $\mathrm{x}$ texture & 2 & 1.347 & 2.431 & 0.121 \\
\hline
\end{tabular}




\begin{tabular}{|c|l|l|l|l|}
\hline Taste / smell $\mathrm{x}$ texture & 2 & 0.010 & 0.018 & 0.894 \\
\hline Nutritional $\mathrm{x}$ taste / smell $\mathrm{x}$ texture & 2 & 0.075 & 0.315 & 0.575 \\
\hline $\begin{array}{c}\text { Adjusted model: } \mathrm{F}=177.742 ; \mathrm{p}=0.000 . \\
\text { Adjusted R squared: } 0.545\end{array}$ & & & & \\
\hline
\end{tabular}

Source: Own elaboration

Table 6 presents the analysis of hypotheses $\mathrm{H}_{4}$ to $\mathrm{H}_{6}$ and the interaction effect among these attributes. Similarly to the analysis carried out in health values, in order to evaluate the contribution of environmentalism to the variance in restaurateur satisfaction, the results of this ANOVA model in our sample highlighted that the safety in organic food has a direct impact on the restaurateur satisfaction including food to be consumed, cleanliness, foodborne illness possibilities and the overall restaurant environment (Sign. p-value < 0.05), but no significant impact on satisfaction was founded in terms of interaction (see Table 6: Sign. p-value $>0.05)$.

Because customers perceive that organic food positively affect their health, chiefs and managers feel satisfied when their customers consuming organic products, thereby increasing interest in elaborating safety foods.

In summary, this analysis determined the relationship between the organic food safety concern and restaurateur satisfaction on the sample. Hypotheses $\mathrm{H}_{4}$ to $\mathrm{H}_{6}$ were tested and only $\mathrm{H}_{5}$ was accepted with the results shown in Table 6 .

Table 6

Hypothesis related to the impact of environment-focused values on satisfaction $\left(\mathrm{H}_{4}-\mathrm{H}_{6}\right)$

\begin{tabular}{|l|c|c|c|c|}
\hline \multicolumn{1}{|c|}{ SOURCE OF VARIATION } & $\begin{array}{c}\text { DEGREES OF } \\
\text { FREEDOM }\end{array}$ & $\begin{array}{c}\text { ROOT MEAN } \\
\text { SQUARE }\end{array}$ & F & Sign \\
\hline Environmental aspects & 2 & 3.698 & 2.938 & 0.057 \\
\hline Food safety concern & 2 & 3.508 & 3.387 & 0.038 \\
\hline Perceived quality & 2 & 1.229 & 0.674 & 0.512 \\
\hline Environment $x$ safety & 2 & 0.922 & 1.093 & 0.297 \\
\hline Environment $x$ quality & 2 & 0.972 & 1.151 & 0.285 \\
\hline Safety x quality & 2 & 0.600 & 0.711 & 0.400 \\
\hline Environment $x$ safety $x$ quality & 2 & 1.377 & 1.631 & 0.203 \\
\hline \multicolumn{2}{|l|}{ Adjusted model: $\mathrm{F}=127.649 ; \mathrm{p}=0.021$. Adjusted R squared: 0.457} \\
\end{tabular}

Source: Own elaboration.

Table 7 presents descriptive statistics for the variables of interest. A detailed analysis of Table 7 reveals high scores in the following attributes: 'taste / smell' in The Mediterranean Coast (mean value: 9.30); 'environmental aspects' in The Mediterranean Coast (mean value: 9.57) and The South of Spain and The Islands (mean value: 9.18). Also, 'food safety concern' was one of the best valued items in The Mediterranean Coast of Spain (mean value: 9.07). 
Table 7

Descriptive statistics on restaurateur satisfaction (sampled restaurant descriptions)

\begin{tabular}{|c|c|c|c|c|c|}
\hline & \multirow{2}{*}{$\begin{array}{c}\text { PENINSULAR } \\
\text { SPAIN } \\
(\mathrm{n}=29)\end{array}$} & \multirow{2}{*}{$\begin{array}{l}\text { MEDITERRANEAN } \\
\text { COAST }(\mathrm{n}=40)\end{array}$} & \multirow{2}{*}{$\begin{array}{l}\text { THE SOUTH OF } \\
\text { SPAIN AND THE } \\
\text { ISLANDS }(n=40)\end{array}$} & \multicolumn{2}{|c|}{ VALUES } \\
\hline & & & & Min. & Max. \\
\hline \multicolumn{6}{|c|}{ HEALTH VALUES: } \\
\hline $\begin{array}{l}\text { Nutritional } \\
\text { attributes }\end{array}$ & 8.55 & 8.42 & 8.18 & 5 & 10 \\
\hline Taste / smell & 8.90 & 9.30 & 8.48 & 5 & 10 \\
\hline Texture & 8.14 & 8.43 & 8.30 & 1 & 10 \\
\hline \multicolumn{6}{|c|}{ ENVIRONMENT-FOCUSED VALUES: } \\
\hline $\begin{array}{l}\text { Environmental } \\
\text { aspects }\end{array}$ & 8.93 & 9.57 & 9.18 & 5 & 10 \\
\hline $\begin{array}{l}\text { Food safety } \\
\text { concern }\end{array}$ & 8.51 & 9.07 & 8.58 & 7 & 10 \\
\hline $\begin{array}{l}\text { Perceived } \\
\text { quality }\end{array}$ & 8.07 & 8.22 & 7.88 & 5 & 10 \\
\hline
\end{tabular}

Source: Own elaboration.

The result of this descriptive analysis provided additional evidences and our findings suggest that statistical differences on most of the items could be found. Given that the objective of the present study was to evaluate the relevance of further information concerning organic products on restaurateurs, the effect of geographic proximity of food products was measured using the satisfaction scale as the dependent variable. In this sense, Table 8 presents group-mean values and a t-test analysis for the satisfaction scale in Spain by geographical area was conducted. The result of this analysis suggests that statistical differences between the peninsula and the coasts were found, with significantly lower values for peninsular regions than the coasts of Spain. This result is according to the review of the literature (Cambourne and Macionis 2003; Lea and Worsley 2005; Chen 2009; Smith et al. 2009; Zakowska-Biemans 2011; Pino et al. 2012; Anenberg and Kung 2015). The findings reported in this study confirm that organic products were evaluated differently according to the information given concerning their region of origin (see Table 8). This effect has been reported in several studies (O'Fallon et al. 2007; De Magistris and Gracia 2008; Instituto Cajamar 2008; MAGRAMA 2014b; Cerdá and Robina 2015a). Previous studies have also found that organic labels are associated with variations in expectation, food judgment and consumption. Hughner et al. (2007), Murphy and Smith (2009), MAGRAMA (2014a) and Robina et al. (2015) found that descriptive menu labels increased post-consumption sensory ratings compared to the non-organic menu items. 
Table 8

T test, means (M), Standard Deviation (SD) and Satisfaction by Region in Spain

\begin{tabular}{|l|c|c|c|c|c|}
\hline & $\mathrm{M} / \mathrm{SD}$ & $\begin{array}{c}\text { PENINSULAR } \\
\text { SPAIN } \\
(\mathrm{n}=29)\end{array}$ & $\begin{array}{c}\text { MEDITERRANEAN COAST } \\
(\mathrm{n}=40) \text {, THE SOUTH OF SPAIN } \\
\text { AND THE ISLANDS (n=40) }\end{array}$ & $\mathrm{t}$ & Sign. \\
\hline $\begin{array}{l}\text { Restaurateur } \\
\text { satisfaction }\end{array}$ & $9.04 / 1.43$ & 8.48 & 9.36 & 4.844 & 0.000 \\
\hline
\end{tabular}

Source: Own elaboration.

\section{CONCLUSIONS, LIMITATIONS AND FURTHER RESEARCH}

More and better insights grounded in empirically based findings are essential in order to alert organic restaurants to the necessity of being open to the needs and feelings of consumers and restaurateurs. Although many questions have to be taken into consideration in the restaurant's decision to purchase organic foods, this study is only focused on describing their behavior when they are disseminating information in their marketing tasks.

Despite the disparate importance of value chain activities in organic restaurants, fortunately there is evidence that management process can be improved in a relatively short time through appropriate promotion. Targeted satisfaction interventions have resulted in substantial gains in test scores also have improved organic restaurant performance in several countries and furthermore, this promotional process has increased satisfaction of consumers, managers and chefs at restaurants. The removal of barriers to commercial success is of particular interest in the context of current efforts in order to increase the number of restaurants promoting the organic food.

In summary, this study has examined the effects of nutritional attributes taste smell and texture of the organic items on the menus, and the importance of environmental aspects food safety concern and perceived quality of the organic food on the restaurateur satisfaction in their promotion process. Regarding to the six research hypotheses pointed out at the beginning of this paper, the healthy attributes of organic food and the environment-focused values of the menus are revealed as key factors to determine the satisfaction of the managers in restaurant business. That is, for restaurateurs taste and smell of organic products are best scored regarding the health values; however for environmentalism, food safety concern is the key indicator for success.

Also, this research highlights that certain attributes of the organic items such as prevention-based focus are relevant on restaurateur satisfaction. Issues such as safety security and responsibility are of concern to the prevention-focused restaurateur. The main theoretical contributions practical implications limitations and further research that emerge from this study are showed below.

The results of this study reveal that smell and taste of the organic products significantly influence on the restaurateur satisfaction when managers and chefs are performing some promotional tasks. These results are in the line of research on this topic.

Regarding the health values of the organic food for managers and chefs, smell and taste are very important attributes to be taken into consideration. These aspects are best valued 
for restaurateurs; that is, they are more interested in the health and responsibility of the commercial offers when they are disseminating information for their consumers. In terms of the environment-focused values, specifically for Spanish restaurateurs, food safety concern is an essential aspect for satisfaction. In summary, these results show that it is very important to consider the target audience when designing the organic menu.

From an academic perspective, there are few studies that point out similar relationships between constructs investigated here, largely because of the unequal presence of organic food in the food service market, the consumption of which is still not widespread in several countries or regions in the world. In terms of implication for practice, these results are relevant for chefs and managers; they have to take into account the costs of implementing and maintaining the organic menu appearance, but also aspects associated to improve the perceptions experiences and attitudes of the restaurateurs (i.e. chiefs and managers) when they are disseminating information to promote their restaurants. Thus, smell and taste of organic products as well as safety concern of food are attributes whose combination allows to improve the level of satisfaction of the restaurants. In addition, chefs and managers should take into account the profile of consumers when they are presenting some relevant information in restaurants, because of diverse combinations of health and environment-focused values impact differently according to the profile of the organic restaurateur.

The knowledge of the above analysis in this study is relevant for promoting organic restaurants in order to reduce the uncertainty involved in risky decisions made by those planning commercial areas and the revitalization of hospitality businesses (including service and retail). E.g.: both private entrepreneurs as public authorities are the different stakeholders that could take advantage from the findings of the work.

Here, it is important to point out that in this study different combinations of attributes of an organic menu are considered; therefore, it is possible that managers owners or chefs of the restaurant establishments are guided by utilitarian criteria related to the level of importance in healthy and environmentally friendly concern, when disseminating the information referred to their restaurant and commercial offer. Furthermore, it would be interesting to analyze also other types of businesses such as those related to recreational services, labeled products, etc.

In this research, an important aspect to be considered is that only restaurateurs in faceto-face interviews and traditional restaurants have participated in this research. Thus, we didn't test specific variables on online marketing, in this sense conclusions should be only adapted in face-to-face experiences promoting organic food in the restaurant. It will be interesting and relevant to research in the future on online marketing related to virtual environments different profiles of users (researchers, retailers), etc.

Finally, this study is only focused on a reduced number of relevant variables for each factor of the menu design: healthy attributes and environment-focused values. In essence, this research is exploratory and descriptive, and given that there are data from different Spanish regions, further research analyzing moderating effects with multi-group analysis will be of interest. In practice, it is also observed that different means of communication (for example, virtual reality 3D technologies films or videos) provide a more entertained and involved dimension to transmit any information; these aspects are key factors for success, when consumers interested in organic food are searching online information. Some of these communicative tools include the use of avatars, virtual assistants, actors, etc., they 
affect the way in which gender becomes a relevant factor related to the satisfaction of the consumers. Further research in this line would highlight on the way in which consumers are learning; this is also great value information for restaurants in order to improve their commercial success in the competitive food service market.

\section{ACKNOWLEDGEMENTS}

This research has been supported by the Ministerio de Agricultura Alimentación y Medio Ambiente (MAGRAMA) Spain. The authors gratefully acknowledge the assistance of the Sociedad Española de Agricultura Ecológica (SEAE), Spain, with the creation of the database used for this research.

\section{REFERENCES}

Aertsens, J., Mondelaers, K., Verbeke, W., Buysse, J. and Huylenbroeck, J., 2011. The influence of subjective and objective knowledge on attitude motivations and consumption of organic food. British Food Journal Bingley, 113(11), 1353-1378.

Ajzen, I. and Fishbein, M., 1975. Belief attitude intention and behavior: an introduction to theory and research. Reading, MA: Addison-Wesley.

Ajzen, I. and Fishbein, M., 2005. The influence of attitudes on behaviour. In: Albarracín, D., Johnson, B. T and Zanna, M. P. (eds.): The handbook of attitudes, 173-221, Mahwah, NJ: Erlbaum.

Anenberg, E. and Kung, E., 2015. Information technology and product variety in the city: The case of food trucks. Journal of Urban Economics, 90, November, 60-78.

Baron, R.M. and Kenny, D.A., 1986. The moderator-mediator distinction in social psychological research. Journal of Personality Social Psychology, 51(6), 1173-1182.

Bauer, H. H., Heinrich, D. and Schäfer, D. B., 2013. The effects of organic labels on global local and private brands. More hype than substance? Journal of Business Research, 66, 1035-1043: http://dxdoiorg/101016/jjbusres201112028

Boyne, S. and Hal, D., 2004. Place promotion through food and tourism: Rural branding and the role of websites. Place Branding, 1(1), 80-92.

Bryła, P., 2016. Organic food consumption in Poland: Motives and barriers. Appetite, 105, 737-746.

Cambourne, B.and Macionis, N., 2003. Linking food wine and tourism: The case of the Australian capital region. In: C. M., Hall, L., Sharples, R., Mitchell, N., Macionis and B., Cambourne (eds). Food Tourism Around the World: Development Management and MarketsBoston. MA: Butterworth-Heinemann, 268-284.

Camillo, A., Kim, W. G., Moreo, P. J. and Ryan, B., 2010. A model of historical development and future trends of Italian cuisine in America. International Journal of Hospitality Management, 29(4), 549-558.

Campbell, J. and DiPietro, R., 2014. Sign of the times: Testing consumer response to local food signage within a casual dining restaurant. Journal of Retailing and Consumer Services, 21, 812-823. 
Carpenter, T. and Reimer, J., 2005. Unethical and fraudulent financial reporting: applying the theory of planned behavior. Journal of Business Ethics, 60, 115-129.

Cerdá, L. M. and Robina, R., 2015a. ¿Todos comemos lo mismo? Un estudio exploratorio sobre la propuesta de valor de la restauración ecológica en España. In: Fraiz, J. A. (ed.): XXV Jornadas Hispano-Lusas de Gestión Científica, Universidad de Vigo, Ourense (España). February, 1-11.

Cerdá, L. M. and Robina, R., 2015b. 'Eco-restauarantes: negocios con mensaje. Revista Ae Agricultura y ganadería ecológica, 20, Summer, 40-42.

Chen, J. and Gursoy, D., 2001. An investigation of tourists' destination loyalty and preferences. International Journal of Contemporary Hospitality Management, 13, 79-85.

Chen, M.-F., 2009. Attitude toward organic foods among Taiwanese as related to health consciousness environmental attitudes and the mediating effects of a healthy lifestyle. British Food Journal, 111, 165-178.

Chryssohoidis, G. M. and Krustallis, A., 2005. Organic consumer's personal values research: testing and validating the list of values (LOV) scale and implementing a value based segmentation task. Food Quality and Preference, 16(7), October, 585-599.

Chuck, C., Fernandes, S. A., and Hyers, L., 2016. Awakening to the politics of food: Politicized diet as social identity. Appetite, 107, December, 425-436 (first online).

Cordano, M. and Frieze, I., 2000. Pollution reduction preferences of US environmental managers: applying Ajzen's theory of planned behaviour. Academy of Management Journal, 43, 627-641.

Cuperschmid, N. R. and Tavares, M. C., 2002. Attitudes towards the environment and its influence in the process of buying food. Rhyme - Interdisciplinary Journal of Marketing, 1(3), September-December, 5-14.

Daunfeldt, S. and Rudholm, N., 2014. Does shelf-labeling of organic foods increase sales? Results from a natural experiment. Journal of Retailing and Consumer Services, 21, 804-811.

Davies, A., Titterington, A. J. and Cochrane, C., 1995. Who buys organic food? A profile of the purchasers of organic food in Northern Ireland. British Food Journal, 97, 17-23.

De Magistris, T. and Gracia, A., 2008. The decision to buy organic food products in Southern Italy. British Food Journal, 110, 929-947.

FEHR, 2012. Los sectores de la hostelería en 2012. Madrid: FEHR.

Gagić, S., Erdeji, I., Mikšić, D. and Petrović, M. D., 2015. New Trends in Restaurant Industry: Serving Locally Produced and Organic Food. KNOWLEDGE - International Journal Scientific and Applicative Papers, 8(1), 176-181.

Goetzke, B., Nitzko, S. and Spiller, A., 2014. Consumption of organic and functional food. A matter of well-being and health? Appetite .77, 94-103.

Hair, J. F., Anderson, R. E., Tatham, R. L. and Black, W. C., 1998. Multivariate Data Analysis. NJ: Ed Englewood Cliffs, Prentice-Hall.

Harper, G. C. and Makatouni, A., 2002. Consumer perception of organic food production and farm animal welfare. British Food Journal, 104, 287-299.

Harris, K., Hanks, L., Line, N. and McGinley, S., 2017. Understanding responses to posted restaurant food safety scores: An information processing and regulatory focus perspective. International Journal of Hospitality Management, 60, January, 67-76 (first online). 
Hoek, A. C., Pearson, D., James, S. W., Lawrence, M. A. and Friel, S., 2017. Shrinking the food-print: A qualitative study into consumer perceptions experiences and attitudes towards healthy and environmentally friendly food behaviours. Appetite, 108, January, 117-131 (first online).

Hsieh, M.-F. and Stiegert, K. W., 2011. Store format choice in organic food consumption. Journal of Agricultural and Applied Economics. College Station, 92(2), 307-313.

Hughner, R. S., McDonagh, P., Prothero, A., Shultz, C. J. and Stanton, J., 2007. Who are organic food consumers? A compilation and review of why people purchase organic food. Journal of Consumer Behaviour, 6, 1-17.

Hutchins, R. K. and Greenhalgh, L. A., 1997. Organic confusion: sustaining competitive advantage. British Food Journal, 99(9), 336-338.

IFOAM, 2013. International Federation of Organic Agriculture Movements. Available online: http://ifoamorg/public/Press_Release_IFOAM_FiBL_final_ENpdf [accessed 11.12.2013].

Instituto Cajamar, 2008. El Mercado de los productos ecológicos. Tarragona: Proyecto Vida.

Jacob, C. and Guéguen, N., 2015. Does the geographic proximity of products influence a consumer's decision? An evaluation in a restaurant. Research Notes and Reports / Annals of Tourism Research, 52, May, 161-179.

Jeong, M. and Lambert, C., 2001. Adaptation of an information quality framework to measure customers' behavioural intentions to use lodging web sites. International Journal of Hospitality Management. 20, 129-146.

Kang, J., Junb, J. and Arendt, S., 2015. Understanding customers' healthy food choices at casual dining restaurants: Using the Value-Attitude-Behavior model. International Journal of Hospitality Management, 48, May, 12-21.

Kim, H. Y. and Chung, J.-E., 2011. Consumer purchase intention for organic personal care products. Journal of Consumer Marketing, 28(1), 40-47.

Kim, W. and Kim, D., 2004. Factors affecting online hotel reservation intention between online and non-online customers. International Journal of Hospitality Management, 23, 381-395.

Kwok, L., Huang, Y.-K. and Hu, L., 2016. Green attributes of restaurants: What really matters to consumers? International Journal of Hospitality Management, 55, May, 107-117.

Lai, W. T., and C. F. Chen, 2011. Behavioral intentions of public transit passengers-The roles of service quality, perceived value, satisfaction and involvement. Transport Policy, 18 (2), 318-325.

Lea, E. and Worsley, T., 2005. Australians' organic food beliefs demographics and values. British Food Journal. 107, 855-869.

Lee, J., Hsu, L., Han, H. and Kim, Y. (2010). Understanding how consumers view green hotels: how a hotel's green image can influence behavioural intentions. Journal of Sustainable Tourism, 18 (7), 901-914.

Lin, H. and Lee, G., 2006. Effects of socio-technical factors on organizational intention to encourage knowledge sharing. Management Decision. Vol. 44, pp. 74-88.

Lockie, S., Lyons, K., Lawrence, G. and Mummery, K., 2002. Eating green: motivations behind organic food consumption in Australia. Sociologia Ruralis, 42(1), 23-40. 
Magnusson, M. K., Arvola, A., Hursti, U., Aberg, L. and Sjoden, P., 2003. Choice of organic food is related to perceived consequences for human health and to environmentally friendly behaviour. Appetite, 40, 109-117.

Mallinson, L. J., Russell, J. M. and Barker, M. E., 2016. Attitudes and behaviour towards convenience food and food waste in the United Kingdom' Appetite, 103, August, 17-28.

Manaktola, K. and Jauhari, V., 2007. Exploring consumer attitude and behaviour towards green practices in the lodging industry in India. International Journal of Contemporary Hospitality Management, 19, 364-377.

Marketzki, A. and Tuckermanty, E., 2007. Community food projects and food system sustainability. In: Hinrichs, C. C. and Lyson, T. (eds.): Remaking the North American Food System: Strategies for Sustainability. University of Nebraska Press, Lincoln, N. E., 332-344.

Martinez, S., Hand, M., DaPra, M., Pollack, S., Ralston, K., Smith, T., Vogel, S., Clark, S., Lohr, L., Low, S. and Newman, C., 2010. Local Food Systems: Concepts, Impacts, and Issues. United States Department of Agriculture Economic Research Service, ERR97. Available from: http://agmarketing.extension.psu.edu/ComFarmMkt/PDFs/ local_food_system.pdf [accessed 08.30.13].

Mikkelsen, B. E., 1993. Organic foods in catering. Nutrition and Food Science, 3, 24-26.

Ministerio de Agricultura Alimentación y Medio Ambiente, MAGRAMA, 2014a. Datos de consumo alimentario en España 2013. http://wwwmagramagobes/es/alimentacion/temas/consumo-y-comercializacion-y-distribucion-alimentaria/PRESENTACION_DATOS_CONSUMO_2013_tcm7-321988pdf [accessed 09-11-2014].

Ministerio de Agricultura Alimentación y Medio Ambiente, MAGRAMA, 2014b. La alimentación mes a mes http:/wwwmagramagobes/es/alimentacion/temas/consumo-y-comercializacion-y-distribucion alimentaria/PRESENTACION_DATOS_CONSUMO_2013_tcm7-321988pdf [accessed 09-11-2014].

Mondelaers, K., Verbeke, W. and van Huylenbroeck, G., 2009. Importance of health and environment as quality traits in the buying decision of organic products. British Food Journal, 111, 1120-1139.

Morris, M. G., Venkatesh, V. and Ackerman, P. L., 2005. Gender and age differences in employee decisions about new technology: an extension to the theory of planned behavior. IEEE Transactions on Engineering Management, 52, 69-84.

Murphy, J. and Smith, S., 2009. Chefs and suppliers: An exploratory look at supply chain issues in an upscale restaurant alliance. International Journal of Hospitality Management, 28, 212-220.

Namkung, Y., and Jang, S., 2007. Does food quality really matter in restaurants? Its impact on customer satisfaction and behavioral intentions. Journal of Hospitality and Tourism Research, 31 (3), 387-410.

O'Fallon, M., Gursoy, D. and Swanger, N., 2007. To buy or not to buy: impact of labeling on purchasing intentions of genetically modified foods. International Journal of Hospitality Management, 26, 117-130.

OTA, Organic Trade Association, 2013. Organic industry survey in 2013. Available online: http://wwwotacom [accessed 11-25-2014].

Ozdemir, B., Caliskan, O., 2014. A review of literature on restaurant menus: specifying the managerial issues. International Journal of Gastronomy and Food Science, 2 (1), 3-13. 
Pino, G., Peluso, A. M. and Guido, G., 2012. Determinants of regular and occasional consumers' intentions to buy organic food. The Journal of Consumer Affairs, 46(1), 157169.

Poulston, J., Yau Kwong, K. and Yiu, A., 2011. Profit or principles: Why do restaurants serve organic food? International Journal of Hospitality Management, 30(1), March, 184-191.

Prada, M., Garrido, M. V. and Rodrigues, D., 2017. Lost in processing? Perceived healthfulness, taste and caloric content of whole and processed organic food. Appetite, 114, 175-186.

Price, S., Hartwell, H., Hemingway, A. and Chapleo, C., 2016. Workplace foodservice; perception of quality and trust. Appetite, 97, February, 169-175.

Price, S., Viglia, G., Hartwell, H., et al., 2016. What are we eating? Consumer information requirement within a workplace canteen. Food Quality and Preference, 53, 39-46.

Quintal, V.A., Lee, J.A. and Soutar, G. N., 2010. Risk uncertainty and the theory of planned behavior: a tourism example. Tourism Management, 31(6), 797-805.

Raab, C., Mayer, K., Kim, Y.-S. and Shoemaker, S., 2009. Price-sensitivity measurement: a tool for restaurant menu pricing. Journal of Hospitality \& Tourism Research, 33 (1), 93-105.

Raab, C. and Mayer, K., 2007. Menu engineering and activity-based costing e can they work together in a restaurant? International Journal of Contemporary Hospitality Management, 19(1), 43-52.

Rivera, J., 2007. Re-evaluating green marketing strategy: A stakeholder perspective. European Journal of Marketing, 41 (11/12), 13-28.

Roberts, K. R., Barrett, B. B., Howells, A. D., Shanklin, C. W., Pilling, V. K. and Brannon, L. A., 2008. Food safety training and foodservice employees' knowledge and behavior. Food Protection Trends, 28, 252-260.

Robina, R., Cerdá, L. M. and Equipo Técnico SEAE, 2015. Estudio de la situación actual y perspectivas de la restauración ecológica en España. Catarroja: SEAE.

Schleenbecker, R. and Hamm, U., 2013. Consumers' perception of organic product characteristics. A review. Appetite, 71, 420-429.

Sharma, A., Moon, J., Strohbehn, C., 2014. Restaurant's decision to purchase local foods: Influence of value chain activities. International Journal of Hospitality Management, 39, 130-143.

Shepperd, R., Magnusson, M. and Sjöden, P-O., 2005. Determinants of consumer behavior related to organic foods. Ambio, 34(4-5), 352-359.

Sirieix, L., Kledal, P. R. and Sulitang, T., 2011. Organic food consumers' trade-offs between local or imported, conventional or organic products: A qualitative study in Shanghai. International Journal of Consumer Studies, 35(6), 670-678.

Smith, T. A., Lin, B-H. and Huang, C. L., 2009. Growth and development in the US retail organic food sector. Sustainability, 1, September, 573-591.

Sundbo, J., 2016. Food scenarios 2025: Drivers of change between global and regional. Futures, 83, October, 75-87.

Tarkiainen, A. and Sundqvist, S., 2005. Subjective norms attitudes and intentions of Finnish consumers in buying organic food. British Food Journal, 107(11), 808-822.

Thøgersen, J., 2017. Sustainable food consumption in the nexus between national context and private lifestyle: A multi-level study. Food Quality and Preference, 55, January, 16-25 (first online). 
Torjusen, H., Lieblein, G., Wandel, M. and Francis, C. A., 2001. Food system orientation and quality perception among consumers and producers of organic food in Hedmark County Norway. Food Quality and Preference, 12, 207-216.

Vega, C. and Ubbink, J., 2008. Molecular gastronomy: a food fad or science supporting innovative cuisine? Trends in food Science \& technology, 19(7), 372-382.

Vitters $\varnothing$, G. and Tangeland, T., 2015. The role of consumers in transitions towards sustainable food consumption. The case of organic food in Norway. Journal of Cleaner Production, 92, 91-99.

Willer, H., Lernoud, J. and Kilcher, L., 2013. The World of Organic Agriculture Statistics and Emerging Trends 2013 Research Institute of Organic Agriculture (FiBL) Bonn: Frickand International Federation of Organic Agriculture Movement (IFOAM).

Yim, E.S., Lee, S. and Kim, W.G., 2014. Determinants of a restaurant average meal price: an application of the hedonic pricing model. International Journal of Hospitality Management, 39, 11-20.

Zakowska-Biemans, S., 2011. Polish consumer food choices and beliefs about organic food. British Food Journal, 113(1), 122-137.

Zanoli, R., Bähr, M., Borschen, M., Laberenz, H., Naspetti, S. and Thelen, E., 2004. The European consumer and Organic Food Organic Marketing Initiatives and Rural Development, IV (175), School of Management \& Business: The University of Wales Aberystwyth. 